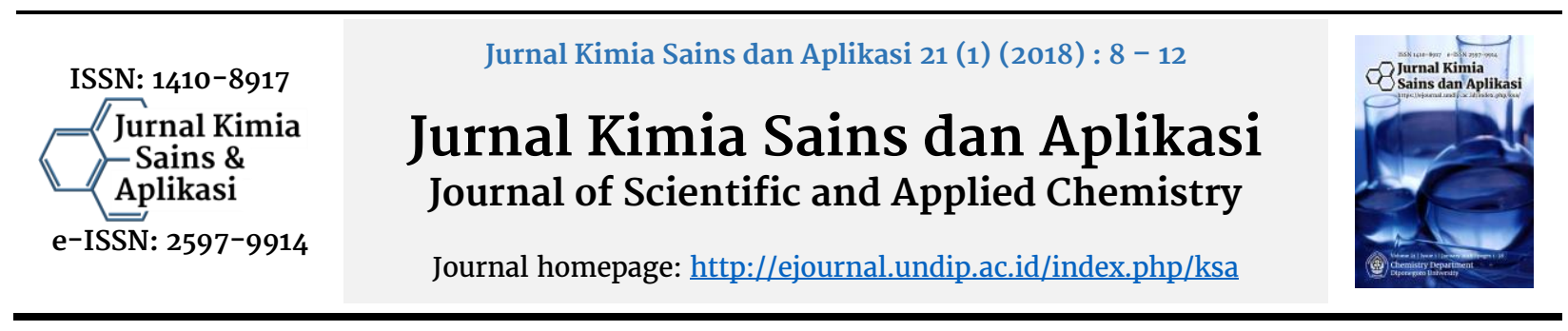

\title{
Antibacterial Activity of Cinnamic Acid - Chitosan Encapsulation
}

\author{
Nur Amaliyah ${ }^{a}$, Ngadiwiyana ${ }^{a}$, Purbowatiningrum Ria Sarjono ${ }^{\mathrm{a},{ }^{*}}$, Ismiyarto $^{\mathrm{a}}$ \\ a Chemistry Department, Faculty of Sciences and Mathematics, Diponegoro University, Jalan Prof. Soedarto, Tembalang, Semarang \\ * Corresponding author: purbowatining@live.undip.ac.id
}

Article Info

Keywords:

Cinnamic acid,

Encapsulation,

Chitosan

Nanopathic, Drying

frozen, antibacterial
Kata Kunci:

Asam Sinamat,

Enkapsulasi,

Nanopatikel

Kitosan, Freeze

drying, antibakteri

\begin{abstract}
The biggest cinnamon bark is cinnamic acid. The inhibitory activity of bacterial growth of $S$. aureus and E. coli and its abundance in nature becomes the superiority of cinnamic acid as antibacterial. However, the use of cinnamic acid as an antibacterial is still less than optimal because of low solubility in water. One of the latest technologies to address the problem is encapsulation in nanometer size. Encapsulation of cinnamic acid using chitosan nanoparticles as an encapsulation material was shown to increase the activity of cinnamic acid as antibacterial by protecting the active compound, as well as increasing its solubility in water through chitosan-TPP modification. Emulsion formation was performed using Corning LSE Compact at 6,000 rpm for 30 minutes. The formation of chitosan nanoparticles as encapsulation material was done using freeze dryer with freeze drying method. Chitosan was obtained from shrimp chitin with Deacetylation Degree (\% DD) of $85.98 \%$. The synthesis of chitosan nanoparticles yielded an average particle size of $330 \mathrm{~nm}$ with a percentage volume of $29.9 \%$ and $79.1 \%$ with an average size of $5570 \mathrm{~nm}$. The morphological form of nanometer-sized chitosan was smaller and uniform than that of chitosan morphology. Encapsulation efficiency value of $67.304 \%$ makes cinnamic acid has higher activity inhibition of bacterial growth than pure cinnamic acid and chitosan nanoparticles.
\end{abstract}

\section{Abstrak}

Kandungan kulit kayu manis terbesar adalah asam sinamat. Aktivitas daya hambat pertumbuhan bakteri S. aureus dan E. coli serta kelimpahannya di alam menjadi keunggulan asam sinamat sebagai antibakteri. Namun, penggunaan asam sinamat sebagai antibakteri masih kurang optimal karena kelarutan yang rendah dalam air. Salah satu teknologi terkini untuk mengatasi masalah tersebut adalah enkapsulasi dalam ukuran nanometer. Enkapsulasi asam sinamat menggunakan nanopartikel kitosan sebagai bahan enkapsulan ditunjukkan untuk meningkatkan aktivitas asam sinamat sebagai antibakteri dengan cara melindungi senyawa aktif, serta meningkatkan kelarutannya dalam air melalui modifikasi kitosan-TPP. Pembentukan emulsi dilakukan menggunakan Corning LSE Compact dengan kecepatan 6.000 rpm selama 30 menit. Pembentukan nanopartikel kitosan sebagai bahan enkapsulan dilakukan menggunakan freeze dryer dengan metode freeze drying. Kitosan diperoleh dari kitin limbah udang dengan nilai Derajat Deasetilasi (\%DD) sebesar 85,98\%. Sintesis nanopartikel kitosan menghasilkan ukuran partikel rata-rata sebesar $330 \mathrm{~nm}$ dengan volume prosentase $29,9 \%$ dan 79,1\% dengan ukuran rata-rata $5570 \mathrm{~nm}$. Bentuk morfologi kitosan berukuran nanometer lebih kecil dan seragam dibandingkan bentuk morfologi kitosan. Nilai efisiensi enkapsulasi 67,304\% menjadikan asam sinamat memiliki aktivitas daya hambat pertumbuhan bakteri yang lebih tinggi dibandingkan asam sinamat murni dan nanopartikel kitosan. 


\section{Pendahuluan}

Asam 3-fenil-2-propenoat atau asam sinamat merupakan senyawa yang salah satunya berasal dari isolasi kulit kayu manis (Cinnamomum burmanni) famili Lauraceae [1]. Asam sinamat bersifat non-toksik dan memiliki berbagai aktivitas biologis, salah satunya antibakteri [2]. Asam sinamat mampu menghambat pertumbuhan bakteri Gram positif $S$. aureus pada konsentrasi 1,5 ppm dan bakteri Gram negatif E. coli pada konsentrasi 7 ppm [3]. Keunggulan ini menyebabkan asam sinamat sangat prospektif dikembangkan sebagai antibakteri.

Penggunaan asam sinamat sebagai antibakteri masih terbatas karena kelarutannya yang rendah dalam air, yaitu 0,5 gram per liter [4]. Oleh karena itu, diperlukan upaya untuk mengatasi kekurangan asam sinamat tersebut, salah satunya adalah nanoteknologi. Penerapan nanoteknologi dapat meningkatkan stabilitas termal, bioavailabilitas oral, dan kelarutannya dalam air [5]. Salah satu aplikasi nanoteknologi yang saat ini sering digunakan, yaitu nanoenkapsulasi. Hal yang perlu diperhatikan dalam proses enkapsulasi adalah jenis penyalut yang digunakan [6]. Kitosan telah terbukti dapat dijadikan sebagai penyalut $[7,8]$ karena memiliki keunggulan, seperti bersifat non-toksik, mukoadhesif, biodegradable, biocompatible [9], serta memiliki aktivitas sebagai antibakteri.

Penelitian Goy dkk. [10] telah membuktikan bahwa kitosan mampu menghambat pertumbuhan bakteri Gram positif S. aureus pada konsentrasi $1250 \mathrm{ppm}$ dan bakteri Gram negatif E. coli pada konsentrasi 1000 ppm. Kitosan berukuran nano meter dibuat dengan mereaksikan antara kitosan dan natrium tripolifosfatsehingga mampu meningkatkan kelarutannya dalam air [11].

Pada akhirnya, aktivitas antibakteri yang sinergis antara asam sinamat dan kitosan serta kelarutan asam sinamat dalam air yang meningkat diharapkan mampu menjadi solusi untuk meningkatkan aktivitas asam sinamat sebagai antibakteri.

\section{Metode Penelitian}

\section{Alat dan Bahan}

Alat-alat yang digunakan dalam penelitian ini adalah seperangkat alat gelas, seperangkat alat refluks, termometer, neraca analitik (ohaus), magnetic stirrer, sentrifuge 600orpm (Corning LSE Compact), inkubator (Labnes 311DS), Laminar Air Flow (Thermo Scientific), autoklaf, Scanning Electron Microscope (SEM) (JEOL), Fourier Transform Infrared (FTIR) (shimadzu 8201 PC), Freeze Dryer (LL1500), Particle Size Analyzer (PSA) (Microtrac), dan Spektrofotometer UV-Visible (Merck). Bahan-bahan yang digunakan dalam penelitian ini adalah cangkang udang vannamei (Litopenaeus vannamei), aquades, $\mathrm{HCl} 1 \mathrm{~N}$ (p.a., Merck), $\mathrm{NaOH}$ (Merck), NaOCl teknis, indikator PP, kertas saring, asam sinamat (p.a., Sigma Aldrich), sodium tripolyphosphate (Na-TPP) (p.a., Sigma Aldrich), ekstrak ragi (yeast extract), $\mathrm{NaCl}$ (Merck), nutrien agar (Merck), suspensi (stok) bakteri S. aureus dan E. coli, dan tween 80 .

\section{Isolasi Kitin dan Sintesis Kitosan dari Cangkang} Udang

Isolasi kitin dan kitosan dari cangkang udang meliputi beberapa tahap, yaitu deproteinasi, demineralisasi, depigmentasi, dan deasetilasi. Tahap awal dimulai dengan pencucian cangkang udang menggunakan air hangat dan direbus dalam air selama 1 jam. Cangkang udang dikeringkan di bawah sinar matahari. Bahan yang sudah kering dihaluskan menggunakan blender dan diayak pada ayakan 60 mesh.

Tahap awal disebut sebagai deproteinasi. Serbuk cangkang udang yang telah diayak sebanyak 25 gram dimasukkan dalam labu alas bulat $500 \mathrm{~mL}$, kemudian ditambahkan $100 \mathrm{~mL} \mathrm{NaOH} 4 \%(\mathrm{~b} / \mathrm{v})$. Campuran tersebut direfluks selama 1 jam pada temperatur $100^{\circ} \mathrm{C}$ dengan pengadukkan menggunakan magnetic strirrer. Hasil refluks, selanjutnya dicuci menggunakan aquades sampai netral, disaring dan dikeringkan dalam oven selama 2 jam pada temperatur $60^{\circ} \mathrm{C}$.

Tahap berikutnya, demineralisasi. Hasil dari tahap sebelumnya diambil sebanyak 10 gram, kemudian

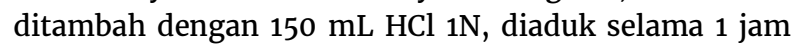
pada temperatur kamar. Proses selanjutnya dicuci dengan aquades sampai filtrat netral dan dikeringkan.

Tahap penghilangan pigmen (zat warna) disebut dengan tahap depigmentasi/ dekolorisasi. Prosesnya, sampel diambil sebanyak 2,5 gram dan ditambahkan dengan $25 \mathrm{~mL} \mathrm{NaOCl}$, kemudian diaduk menggunakan magnetic stirrer selama 1 jam. Hasilnya disaring dan dikeringkan sehingga diperoleh kitin.

Kitin hasil proses sebelumnya diambil sebanyak 1,5 gram, ditambahkan dengan 22,5 mL NaOH, dan direfluks pada suhu $80^{\circ} \mathrm{C}$ selama 1 jam sehingga dihasilkan kitosan. Tahap ini disebut sebagai deasetilasi.

Kitin dan kitosan dianalisis menggunakan Fourier Transform Infrared (FTIR) untuk mengetahui gugusgugus fungsional yang ada di dalamnya.

\section{Sintesis Nanopartikel Kitosan}

Metode yang digunakan dalam sintesis nanopartikel kitosan adalah metode gelasi ionik [12]. Asam asetat glasial $1 \mathrm{~mL}$ diencerkan menjadi $100 \mathrm{~mL}$ menggunakan aquades menghasilkan larutan asam asetat glasial. Kitosan sebanyak 0,1 gram dilarutkan dalam larutan asam asetat glasial menghasilkan larutan kitosan. Na-TPP sebanyak 0,25 gram dilarutkan dalam $100 \mathrm{~mL}$ aquades menghasilkan larutan TPP, kemudian larutan kitosan ditambahkan dengan larutan TPP tetes demi tetes sambil diaduk menggunakan magnetic stirrer selama 1 jam. Larutan agak kental yang dihasilkan, di sentrifuge dengan kecepatan $6000 \mathrm{rpm}$ selama 1 jam sehingga menghasilkan suspensi dan supernatan. Suspensi dikeringkan menggunakan freeze dryersehingga dihasilkan nanopartikel kitosan. Nanopartikel kitosan dianalisis menggunakan Scanning Electron Microscope (SEM) dan Particle Size Analyzer (PSA). 
Enkapsulasi Asam Simanat Dalam Nanopartikel Kitosan

Metode yang digunakan dalam enkapsulasi asam sinamat dengan nanopartikel kitosan adalah freeze drying. Na-TPP sebanyak 0,25 gram dilarutkan dalam $100 \mathrm{~mL}$ aquades menghasilkan larutan TPP. Asam sinamat sebanyak 0,1 gram dilarutkan dalam larutan TPP menghasilkan larutan asam sinamat. Asam asetat glasial sebanyak $1 \mathrm{~mL}$ dilarutkan menjadi $100 \mathrm{~mL}$ menggunakan aqudes sehingga menghasilkan larutan asam asetat glasial. Kitosan sebanyak 0,1 g dilarutkan dalam $100 \mathrm{~mL}$ larutan asam asetat glasial menghasilkan larutan kitosan, kemudian larutan asam sinamat di teteskan ke dalam larutan kitosan.

Larutan agak kental yang dihasilkan, kemudian dilakukan sentrifuge dengan kecepatan 6000 rpm selama 30 menit hingga menghasilkan suspensi dan supernatan. Suspensi dikeringkan menggunakan freeze dryer sehingga dihasilkan serbuk enkapsulasi asam sinamat-kitosan. Serbuk enkapsulasi asam sinamatkitosan kemudian dihitung efesiensi enkapsulasi (\%EE) menggunakan spektrofotometer UV-Visible.

Panjang gelombang dan konsentrasi yang diperoleh, kemudian dibuat grafik [11], selanjutnya dihitung dengan persamaan,

$$
\% \mathrm{EE}=\frac{\text { Konsentrasi awal }- \text { Konsentrasi bebas }}{\text { jumlah total asam sinamat }} \times 100 \%
$$

\section{Uji Aktivitas Antibakteri}

Uji antibakteri dilakukan dengan pengambilan bakteri S. aureus dan E. colisesuai standar Mc. Farland 0,5 dengan 5 variasi konsentrasi, yaitu 250 ppm, 500 ppm, $750 \mathrm{ppm}, 1000 \mathrm{ppm}, 1250 \mathrm{ppm}$. Uji antibakteri pada penelitian ini menggunakan metode difusi cakram.Cakram kertas dengan ukuran diameter 0,55 $\mathrm{mm}$ diimpregnasi dengan larutan ekstrak yang terdiri dari asam sinamat, nanopartikel kitosan, dan hasil enkapsulasi asam sinamat-kitosan.

\section{Hasil dan Pembahasan}

\section{Isolasi Kitin dan Sintesis Kitosan dari Cangkang} Udang

Cangkang udang mengandung beberapa komponen, diantaranya protein, kalsium karbonat, dan kitin.

Tabel 1: Hasil isolasi kitin dan sintesis kitosan dari cangkang udang

\begin{tabular}{cccc}
\hline Tahap & $\begin{array}{c}\text { Berat } \\
\text { sampel }\end{array}$ & $\begin{array}{c}\text { Berat hasil } \\
\text { perlakuan }\end{array}$ & Rendemen \\
\hline Deproteinasi & 25 gram & 15,65 gram & $62,60 \%$ \\
Demineralisasi & 5 gram & 2,63 gram & $52,60 \%$ \\
Depigmentasi & 2,5 gram & 1,62 gram & $64,80 \%$ \\
Deasetilasi & 1,5 gram & 1,186 gram & $79,06 \%$ \\
\hline
\end{tabular}

Isolasi kitin melalui tahap deproteinasi dengan tujuan menghilangkan protein dari cangkang udang. Rendemen yang diperoleh pada tahap ini sebesar $62,60 \%$. Hal ini menunjukkan bahwa lebih dari $50 \%$ protein pada cangkang udang terlepas dan membentuk Na-proteinat yang dapat larut.
Tahap demineralisasi dengan tujuan menghilangkan senyawa anorganik yang terdapat pada cangkang udang. Rendemen yang diperoleh pada tahap ini sebesar 52,60\%, menunjukkan bahwa telah terjadi proses pemisahan mineral pada cangkang udang [13].

Tahap depigmentasi untuk menghilangkan pigmen (zat warna) pada limbah udang menghasilkan rendemen sebesar $64,80 \%$.

Proses selanjutnya, sintesis kitin melalui tahap deasetilasi kitin untuk mengubah gugus asetil ($\left.\mathrm{NHCOCH}_{3}\right)$ pada kitin menjadi gugus amina $\left(-\mathrm{NH}_{2}\right)$ pada kitosan dengan penambahan suhu tinggi. Rendemen yang diperoleh sebesar $79,06 \%$. Hal ini menunjukkan bahwa gugus asetil telah hilang lebih dari $50 \%$ melalui pemutusan ikatan antara karbon pada gugus asetil dengan nitrogen pada gugus amin.

\section{Hasil Analisis Kitin Dan Kitosan}

Keberhasilan isolasi kitin dan sintesis kitosan dapat dilihat melalui analisis menggunakan FTIR, seperti pad gambar dibawah ini.

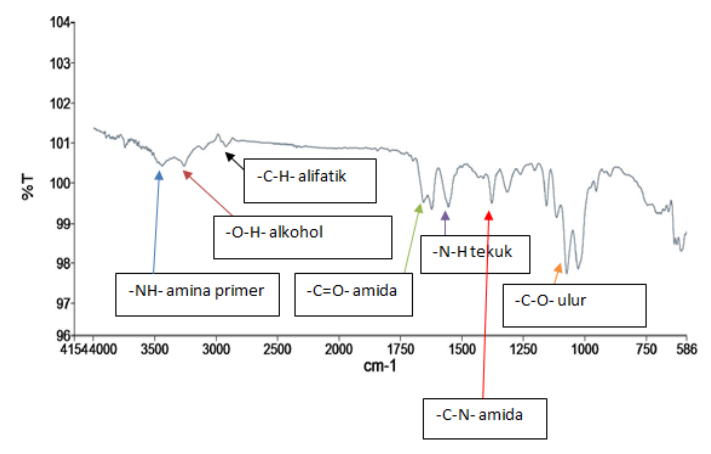

Gambar 1. Spektrum FTIR Kitin

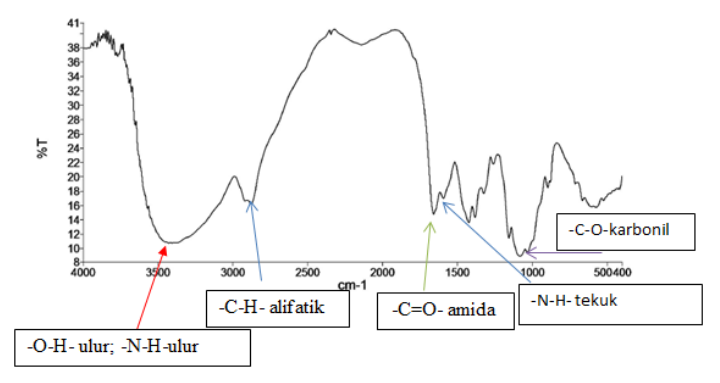

Gambar 2. Spektum FTIR Kitosan

Perbedaan peak yang terlihat jelas antar kitin dan kitosan pada bilangan gelombang sekitar $3500 \mathrm{~cm}^{-1}$. Spektrum kitosan menunjukkan peak yang melebar pada bilangan gelombang sekitar $3500 \mathrm{~cm}^{-1}$ karena $-\mathrm{NH}$ amina primer lebih banyak dibandingkan pada kitin. Hal ini memperlihatkan salah satu keberhasilan sintesis kitosan dengan adanya perubahan gugus fungsi pada kitin. Nilai derajat deasetilasi (DD) sebesar 85,98\%, kitin yang berubah menjadi kitosan sebesar $85,98 \%$. Dibandingkan dengan kitosan dari Brataco dengan DD sebesar $65,63 \%$ [14]. 


\section{Sintesis Nanopartikel Kitosan}

Nanopartikel kitosan dibuat dengan mereaksikan antara kitosan dan Na-TPP. Gugus amina $\left(\mathrm{NH}_{2}\right)$ pada kitosan menjadi bermuatan positif $\left({ }^{+} \mathrm{NH}_{3}\right)$ ketika kitosan dilarutkan dalam asam asetat glasial, sedangkan natrium tripolifosfat yang dilarutkan dalam aquades mengalami ionisasi dan dapat membentuk polianion tripolifosfat. Hal ini mengakibatkan adanya interaksi ionik antara gugus bermuatan positif $\left({ }^{+} \mathrm{NH}_{3}\right)$ dengan gugus bermuatan negatif tripolifosfat $\left(\mathrm{H}_{3} \mathrm{P}_{3} \mathrm{O}_{10}{ }^{2-}\right)$ (Ngah dan Fathinathan, 2010). Hasil karakterisasi kitosan dan nanopartikel kitosan menggunakan SEM ditunjukkan pada gambar 3 .

(a)

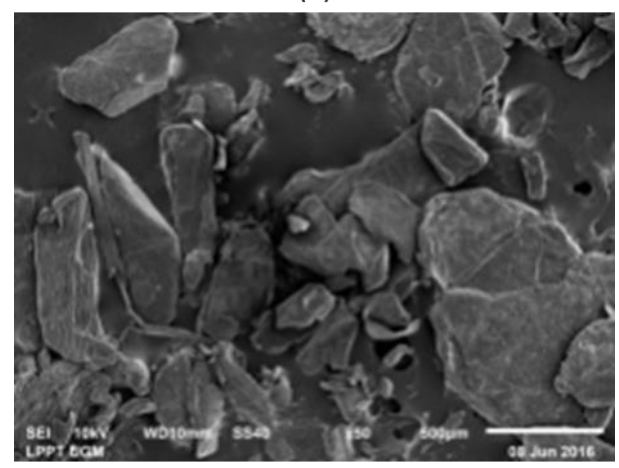

(b)

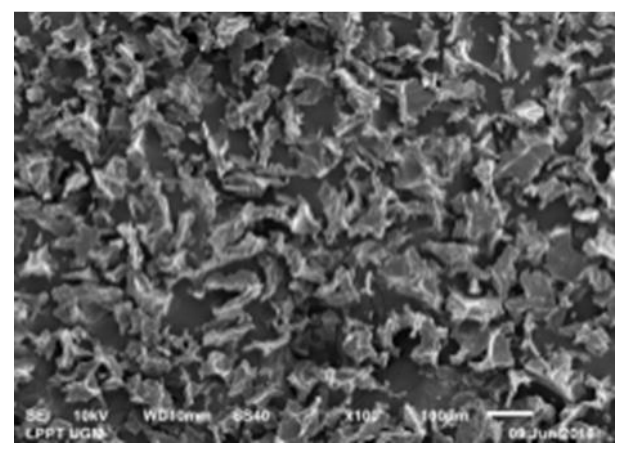

Gambar 3. (A) Hasil asnalisis Scanning Electron Microscope Kitosan; (B) Scanning Electron Microscope Nanopartikel Kitosan.

Terlihat perbedaan morfologi permukaan antara kitosan dan nanopartikel kitosan. Ukuran partikel pada morfologi permukaan nanopartikel kitosan lebih kecil dibandingkan kitosan. Selain itu, nanopartikel memiliki bentuk yang lebih seragam dibandingkan kitosan. Ukuran partikel diinterpretasikan melalui karakterisasi PSA. Berikut adalah hasil karakterisasi PSA.

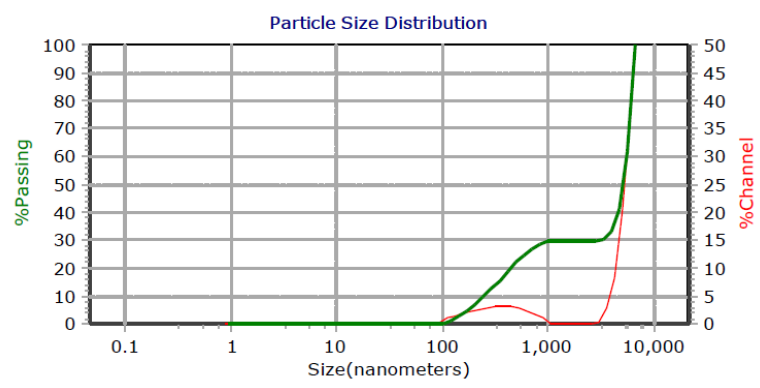

Gambar 4. Hasil analisis nanopartikel kitosan menggunakan Particle Size Analyzer
Berdasarkan hasil karakterisasi menggunakan Particle Size Analyzer ( [15]PSA), distribusi ukuran partikel kitosan menunjukkan bahwa $70,1 \%$ ukuran partikel kitosan belum terbentuk nanopartikel (Gambar 4). Mode pertama memiliki ukuran patikel rata - rata sebesar $5570 \mathrm{~nm}$ dan mode kedua menunjukkan ukuran partikel rata - rata sebesar $330 \mathrm{~nm}$ dengan volume presentase $29,9 \%$ sehingga dapat disimpulkan bahwa partikel yang terbentuk sudah berukuran nano meskipun partikel yang berukuran mikro lebih banyak terbentuk. Hal ini karena nanopartikel kitosan belum terbentuk secara belum menyeluruh.

\section{Hasil Enkapsulasi Asam Sinamat Dalam Nanopartikel} Kitosan

Nilai efisiensi enkapsulasi yang diperoleh pada penelitian ini sebesar $64,304 \%$. Hal ini menunjukkan bahwa kemampuan nanopartikel kitosan dalam menyalut asam sinamat sudah melebihi $50 \%$ dari jumlah asam sinamat awal.

\section{Hasil Uji Aktivitas Antibakteri}

Uji aktivitas antibakteri pada sampel asam sinamat, kitosan, serta hasil enkapsulasi asam sinamat dalam nanopartikel kitosan dilakukan dengan metode cakram pada medium agar yang dibuat variasi konsentrasi 250 ppm; 500 ppm; 750 ppm; 1000 ppm; 1250 ppm menggunakan bakteri gram positif S.aureus dan bakteri gram negatif E.coli. Hasil yang diperoleh dalam uji antibakteri antara asam sinamat, nanopartikel kitosan, dan hasil enkapsulasi asam sinamat-kitosan ditampilkan pada gambar 5 terhadap bakteri gram positif S.aureus dan gambar 6 terhadap bakteri gram negatif E.coli.

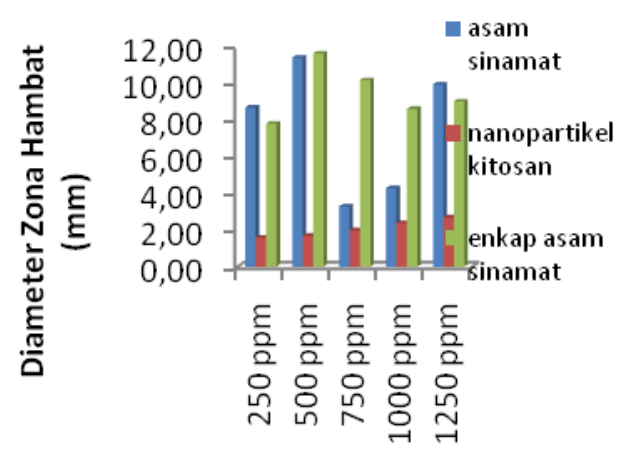

Konsentrasi

Gambar 5. Diagram uji aktivitas terhadap bakteri $S$. aureus

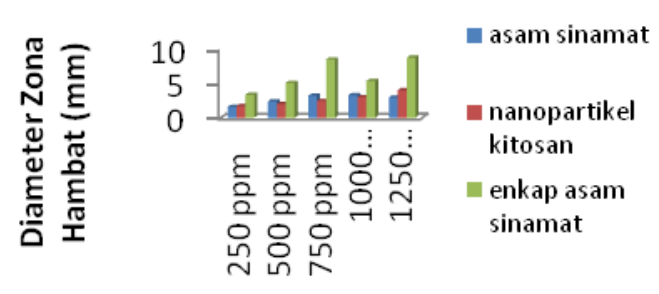

\section{Konsentrasi}

Gambar 6. Diagram uji aktivitas terhadap bakteri E. coli 
Berdasarkan diagram yang terdapat pada Gambar 5 dan6menunjukkan aktivitas antibakteri $S$. aureus danE.coli yang lebih tinggi daripada asam sinamat dan nanopartikel kitosan. Hal ini sesuai dengan hipotesa karena adanya sinergisitas antara asam sinamat dan kitosan yang memiliki aktivitas sebagai antibakteri. Dapat disimpulkan, tujuan enkapsulasi ini telah tercapai dalam meningkatkan aktivitasnya sebagai antibakteri.

\section{Kesimpulan}

Nanopartikel kitosan mampu melindungi senyawa aktif pada asam sinamat melalui proses enkapsulasi, sehingga memiliki aktivitas antibakteri yang lebih baik dibandingkan senyawa murni asam sinamat. Perlu dilakukan penelitian lebih lanjut mengenai penggunaan beberapa variasi konsentrasi antara asam sinamat dengan kitosan sehingga dapat diketahui hasil efisiensi maksimum dan aktivitas antibakteri yang lebih baik.

\section{Daftar Pustaka}

[1] Jeffry Julianus, Elvan Luckyvano, Sintesis Asam Sinamat Dari Benzaldehida Dan Asam Malonat Dengan Katalis Dietilamina, Journal of Pharmaceutical Sciences and Community, 11, 1, (2016)

[2] Marcellino Rudyanto, Lanny Hartanti, Synthesis of Some Cinnamic Acid Derivatives: Effect of Groups Attached on Aromatic Ring to the Reactivity of Benzaldehyde, Indonesian Journal of Chemistry, 8, 2, (2010) 226-230

[3] Sandrina A. Heleno, Isabel C. F. R. Ferreira, Ana P. Esteves, Ana Ćirić, Jasmina Glamočlija, Anabela Martins, Marina Soković, Maria João R. P. Queiroz, Antimicrobial and demelanizing activity of Ganoderma lucidum extract, p-hydroxybenzoic and cinnamic acids and their synthetic acetylated glucuronide methyl esters, Food and Chemical Toxicology, 58, (2013) 95-100 http://dx.doi.org/10.1016/j.fct.2013.04.025

[4] John A Hoskins, The occurrence, metabolism and toxicity of cinnamic acid and related compounds, Journal of Applied Toxicology, 4, 6, (1984) 283-292

[5] Qingrong Huang, Hailong $\mathrm{Yu}$, Qiaomei $\mathrm{Ru}$, Bioavailability and delivery of nutraceuticals using nanotechnology, Journal of food science, 75, 1, (2010)

[6] A Sakha Rujita, Karakteristik Mikrokapsul Minyak Atsiri Lengkuas dengan Maltodekstrin Sebagai Enkapsulan [Characteristics of Galangal Essential Oil Microencapsulation Using Maltodextrin Encapsulant], Jurnal Teknologi dan Industri Pangan, 24, 2, (2013) 201

[7] Cleonice Gonçalves da Rosa, Caroline Dellinghausen Borges, Rui Carlos Zambiazi, Michael Ramos Nunes, Edilson Valmir Benvenutti, Suzane Rickes da Luz, Roseane Farias D'Avila, Josiane Kuhn Rutz, Microencapsulation of gallic acid in chitosan, $\beta$ cyclodextrin and xanthan, Industrial Crops and Products, 46, (2013) 138-146 http://dx.doi.org/10.1016/j.indcrop.2012.12.053

[8] Mike TL Tobing, Nor Basid Adibawa Prasetya, Khabibi Khabibi, Peningkatan Derajat Deasetilasi Kitosan dari Cangkang Rajungan dengan Variasi Konsentrasi NaOH dan Lama Perendaman, Jurnal Kimia Sains dan Aplikasi, 14, 3, (2011) 83-88
[9] R. Harris, E. Lecumberri, I. Mateos-Aparicio, M. Mengíbar, A. Heras, Chitosan nanoparticles and microspheres for the encapsulation of natural antioxidants extracted from Ilex paraguariensis, Carbohydrate Polymers, 84, 2, (2011) 803-806 http://dx.doi.org/10.1016/j.carbpol.2010.07.003

[10] Rejane C Goy, Douglas de Britto, Odilio BG Assis, A review of the antimicrobial activity of chitosan, Polímeros, 19, 3, (2009) 241-247

[11] S. Hassani, A. Laouini, H. Fessi, C. Charcosset, Preparation of chitosan-TPP nanoparticles using microengineered membranes - Effect of parameters and encapsulation of tacrine, Colloids and Surfaces A: Physicochemical and Engineering Aspects, 482, (2015) 34-43 http://dx.doi.org/10.1016/j.colsurfa.2015.04.006

[12] Lok P. Singh, Sriman K. Bhattacharyya, Rahul Kumar, Geetika Mishra, Usha Sharma, Garima Singh, Saurabh Ahalawat, Sol-Gel processing of silica nanoparticles and their applications, Advances in Colloid and Interface Science, 214, (2014) 17-37 http://dx.doi.org/10.1016/j.cis.2014.10.007

[13] Emma Rochima, Karakterisasi kitin dan kitosan asal limbah rajungan cirebon jawa barat, Jurnal Pengolahan Hasil Perikanan Indonesia, 10, 1, (2010) http://dx.doi.org/10.17844/jphpi.v10i1.965

[14] Westriani Prambaningrum, Khabibi Khabibi, Muhammad Cholid Djunaidi, Adsorpsi Ion Besi (III) dan Kadmium (II) Menggunakan Gel Kitosan, Jurnal Kimia Sains dan Aplikasi, 12, 2, (2009) 47-51

[15] W. S. Wan Ngah, S. Fatinathan, Adsorption characterization of $\mathrm{Pb}(\mathrm{II})$ and $\mathrm{Cu}(\mathrm{II})$ ions onto chitosan-tripolyphosphate beads: Kinetic, equilibrium and thermodynamic studies, Journal of Environmental Management, 91, 4, (2010) 958-969 http://dx.doi.org/10.1016/j.jenvman.2009.12.003 